\title{
Penerapan Strategi Pembelajaran Circuit Learning: Suatu Upaya dalam Meningkatkan Hasil Belajar Siswa
}

\author{
Syahrial \\ Dosen Sekolah Tinggi Ilmu Ekonomi (STIE) SUMBAR Pariaman \\ syahrialrajomulie@gmail.com
}

\begin{abstract}
This research is motivated by the low student mathematics learning outcomes. The influencing factors are inactive students and lack of communication between students and students. This study aims to determine the effect of the application of the circuit learning strategy to students' learning outcomes in the cognitive and effective domains. This type of research is preexperimental and the research design used is randomized control group only design. Based on the final test of learning outcomes obtained an average of mathematics learning outcomes in the experimental class 79.3 and the average mathematics learning outcomes of the control class 70 . The results of the t-test analysis obtained tcount $=3.89$ and ttable $=1.667$ at the real level of 0.05. It is concluded that tcount> ttable accepts an alternative hypothesis (H1) that is the mathematics learning outcomes of the experimental class students is better than the control class. Analysis of the data in the affective domain obtained zcount $=3.83$ and ztable $=1.64$ at the real level of 0.05 thus zcount $>$ ztable, in other words Hi is accepted meaning that student learning activities in the experimental class are better than the control class. Based on data analysis in the cognitive and affective domains it can be concluded that there is an influence of the application of the circuit learning strategy to student mathematics learning outcomes.
\end{abstract}

Keyword: circuit learning

\begin{abstract}
Abstrak: Penelitian ini dilatar belakangi oleh rendahnya hasil belajar matematika siswa. Faktor yang mempengaruhi adalah siswa tidak aktif dan kurangnya komunikasi antara siswa dan siswa. Penelitian ini bertujuan untuk mengetahui pengaruh penerapan strategi circuit learning terhadap hasil belajar matematika siswa pda ranah kognitif dan efektif. Jenis penelitian ini yaitu pra eksperimen dan rancangan penelitian yang digunakan adalah randomized control group only design. Berdasarkan tes akhir hasil belajar diperoleh rata-rata hasil belajar matematika pada kelas eksperimen 79,3 dan rata-rata hasil belajar matematika kelas kontrol 70. Hasil analisa uji- $t$ diperoleh $t_{\text {hitung }}=3,89$ dan $t_{\text {tabel }}=1,667$ pada taraf nyata 0,05. Disimpulkan $t_{\text {hitung }}>t_{\text {tabel }}$ menerima hipotesis alternatif $\left(\mathrm{H}_{1}\right)$ yaitu hasil belajar matematika siswa kelas eksperimen lebih baik dibandingkan kelas kontrol. Analisis data pada ranah afektif didapat $\mathrm{z}_{\text {hitung }}=3,83$ dan $\mathrm{z}_{\text {tabel }}=1,64$ pada taraf nyata 0,05 dengan demikian $\mathrm{z}_{\text {hitung }}>\mathrm{z}_{\text {tabel, }}$ dengan kata lain $\mathrm{H}_{\mathrm{i}}$ diterima artinya aktifitas belajar siswa pada kelas eksperimen lebih baik dibandingkan kelas kontrol. Berdasarkan analisis data pada ranah kognitif dan afektif dapat disimpulkan bahwa terdapat pengaruh penerapan strategi circuit learning terhadap hasil belajar matematika siswa.
\end{abstract}

Kata kunci: circuit learning

\section{PENDAHULUAN}

Matematika sebagai ilmu dasar memegang peranan penting dalam membentuk pola pikir peserta didik dan melatih kemampuan penalaran dalam memecahkan berbagai masalah kehidupan. Pembelajaran matematika dapat dilakukan secara formal dan informal. Sekolah sebagai institusi formal memiliki peranan dalam proses pengenalan matematika yang dikembangkan berdasarkan kemampuan peserta didik untuk mengembangkan potensi yang dimiliki dalam menghadapi kehidupan masa depan.

Upaya pengembangan pendidikan salah satunya melalui pembelajaran matematika. Mengingat pentingnya matematika pemerintah telah berupaya memperbaiki kualitas pendidikan matematika dengan cara memperbaiki kurikulum, melengkapi sarana dan prasarana, meningkatkan kompetensi dan mutu guru. Upaya pemerintah dalam meningkatkan kualitas pendidikan matematika tidak akan berjalan dengan sepenuhnya, apabila guru tidak menunjang dalam kegiatan penbelajaran yang dilakukan di sekolah. Selain itu, guru harus memikirkan cara atau strategi pembelajaran yang tepat agar kegiatan pembelajaran dapat berjalan dengan lancar dan efektif. Sehingga tujuan pembelajaran yang diharapkan dapat tercapai dengan baik.

Berdasarkan hasil observasi yang dilakukan di SMPN 4 Lubuk Alung, sebagian besar guru masih menunjukkan bahwa aktivitas siswa dalam pembelajaran matematika masih rendah. Pembelajaran masih berpusat kepada guru, dimana siswa hanya menerima materi yang disampaikan oleh guru. Ketika guru memberikan kesempatan untuk bertanya siswa hanya diam seolah-olah siswa sudah mengerti. Namun apabila diberi soal latihan siswa kesulitan mengerjakannya. 
Berdasarkan hasil wawancara peneliti dengan guru bidang studi matematika kelas VIII SMPN 4 Lubuk Alung, hanya sebagian besar siswa yang mengerjakan tugas yang diberikan oleh guru, sedangkan yang lain hanya mengandalkan temanya. Siswa akhirnya tidak terbiasa dalam menyelesaikan masalah matematika. Hal ini mengakibatkan siswa yang memiliki kemampuan rendah dan tidak memiliki keinginan untuk memahami materi yang dipelajari. Upaya yang telah dilakukan guru untuk menyelesaikan masalah di atas adalah dengan cara merubah gaya belajar yang bervariasi, agar siswa bisa belajar dengan giat. Guru lebih banyak memberikan soal latihan yang berbeda-beda agar siswa tidak terpaku dalam satu soal saja. Guru harus bisa memancing siswa untuk bertanya, dan guru perlu memiliki strategi, pendekatan, model dan teknik pembelajaran yang tepat agar semua siswa dapat ikut serta dalam proses pembelajaran. Jika kondisi ini masih berlanjut, maka akan berdampak buruk bagi siswa. Oleh karena itu, sebagai seorang guru kita harus memberikan strategi yang tepat. Strategi pembelajaran yang diperkirakan dapat menjadi solusi untuk menyelesaikan masalah diatas adalah dengan pembelajaran srategi circuit learning. Circuit Learning merupakan strategi pembelajaran yang memaksimalkan pemberdayaan pikiran dan perasaan dengan pola penambahan (adding) dan pengulangan (repetition). Strategi ini biasanya dimulai dari tanya jawab tentang topik yang dipelajari,penyajian peta konsep, penjelasan mengenai peta konsep, pembagian ke dalam beberapa kelompok, pengisian lembar kerja siswa disertai dengan peta konsep penjelasan tentang tata cara pengisian, pelaksanaan presentasi kelompok, dan pembagian reward atau pujian.

Berdasarkan permasalahan di atas, penulis mencoba melakukan penelitian dengan judul Penerapan Strategi Pembelajaran Circuit Learning: Suatu Upaya dalam Meningkatkan Hasil Belajar Siswa dengan rumusan masalah adalah apakah terdapat pengaruh penerapan strategi circuit learning terhadap hasil belajar matematika siswa kelas VIII SMPN 4 Lubuk Alung”.

Pembelajaran matematika adalah kegiatan guru dalam mengajarkan matematika kepada siswa yang di dalamnya terkandung upaya guru untuk menciptakan pelayanan terhadap kemampuan, potensi, minat, bakat yang beragam agar terjadinya interaksi optimal antara guru dengan siswa serta antara siswa dengan siswa (Suyitno: 2004:2). Pembelajaran matematika yang diterapkan di sekolah hendaknya melibatkan siswa secara aktif dalam pembelajaran.

Salah satu upaya untuk meningkatkan aktivitas belajar siswa yang dapat dilakukan oleh guru adalah pemilihan model pembelajaran. Pemilihan model yang tepat akan meningkatkan aktivitas siswa dan akan memperlancar pembelajaran, sehingga pembelajaran lebih menarik dan tidak membosankan dan pembelajaran tidak terpusat lagi pada guru tetapi terpusat pada siswa. Model pembelajaran yang dapat menarik minat siswa dan dapat meningkatkan aktivitas siswa sehingga dibutuhkan suatu pembelajaran kooperatif dengan cara berdiskusi salah satunya adalah tipe circuit learning.

Menurut Miftahul Huda (2014:311) langkah-langkah pembelajaran Circuit Learning adalah sebagai berikut:

1. Tahap Persiapan

a. Melakukan apersepsi.

b. Menjelaskan tujuan pembelajaran yang harus dicapai oleh siswa dalam pembelajaran hari ini.

c. Menyampaikan cakupan materi dan penjelasan uraian kegiatan.

2. Tahap Kegiatan Inti

a. Melakukan tanya jawab tentang topik yang dibahas.

b. Menempelkan gambar tentang topik tersebut di papan tulis.

c. Mengajukan pertanyaan tentang gambar yang ditempel.

d. Menempelkan peta konsep yang telah dibuat.

e. Menjelaskan peta konsep yang telah ditempel.

f. Membagi siswa menjadi beberapa kelompok.

g. Membagikan lembar kerja kepada setiap kelompok.

h. Menjelaskan bahwa setiap kelompok harus mengisi lembar kerja siswa dan mengisi bagian dari peta konsep sesuai dengan bahasa mereka sendiri.

i. Menjelaskan bahwa bagian dari peta konsep yang mereka kerjakan akan dipresentasikan.

j. Melaksanakan presentasi bagian dari peta konsep yang telah dikerjakan.

k. Memberikan penguatan berupa pujian atau hadiah atas hasil presentasi yang bagus serta memberikan semangat kepada mereka yang belum dapat pujian atau hadiah untuk berusaha lebih giat.

1. Menjelaskan kembali hasil diskusi siswa tersebut agar wawasan siswa menjadi lebih luas.

Jurnal Ilmiah Dikdaya, 9(2), September 2019 


\section{Tahap Penutup}

a. Memancing siswa untuk membuat rangkuman.

b. Melakukan penilaian terhadap hasil kerja siswa.

Strategi pembelajaran Circuit Learning merupakan strategi pembelajaran yang memaksimalkan pemberdayaan pikiran dan perasaan dengan pola penambahan (adding) dan pengulangan (repetition). Strategi ini biasanya dimulai dari tanya jawab tentang topik yang dipelajari, penyajian peta konsep, penjelasan mengenai peta konsep, pembagian ke dalam beberapa kelompok, pengisian lembar kerja siswa disertai dengan peta konsep penjelasan tentang tata cara pengisian, pelaksanaan presentasi kelompok, dan pembagian reward atau pujian.

Sesuai dengan langkah-langkah tersebut, maka langkah-langkah penerapan strategi circuit learning dalam proses pembelajaran matematika pada penelitian ini adalah:

a) Guru mengucapkan salam dan mengarahkan siswa untuk memimpin doa.

b) Guru mengecek kehadiran siswa.

c) Guru memberikan apersepsi tentang konsep materi yang akan dipelajari.

d) Guru memberikan motivasi tentang kegunaan materi pembelajaran dalam kehidupan sehari-hari.

e) Guru menempelkan gambar materi ajar didepan kelas dan memberikan pertanyaan kepada siswa.

f) Guru menempelkan peta konsep dan menjelaskan tentang peta konsep tersebut.

g) Guru membagi siswa dalam beberapa kelompok dan membagikan lembar kerja.

h) Guru menjelaskan bahwa setiap kelompok harus mengisi lembar kerja siswa dan mengisi bagian dari peta konsep sesuai dengan bahasa mereka sendiri.

i) Guru menjelaskan bahwa bagian dari peta konsep yang mereka kerjakan akan dipresentasikan.

j) Peserta didik bersama kelompoknya mendiskusikan lembar kerja yang diberikan guru.

k) Semua anggota kelompok kemudian saling bertukar pikiran dan mendiskusikan masalah yang telah diberikan oleh guru kemudian membuat laporan hasil diskusi.

1) Setelah selesai berdiskusi guru memberikan kesempatan kepada setiap kelompok untuk mempresentasikan peta konsep yang mereka buat dengan bahasa sendiri.

m)Setiap kelompok tampil ke depan kelas untuk mempresentasikan hasil diskusinya.

n) Guru memberikan penguatan berupa pujian atas hasil presentasi yang bagus serta memberikan semangat kepada mereka yang belum dapat pujian atau hadiah untuk berusaha lebih giat.

o) Guru menjelaskan kembali hasil diskusi siswa tersebut agar wawasan siswa menjadi lebih luas.

p) Guru memancing siswa untuk membuat rangkuman.

q) Guru melakukan penilaian terhadap hasil kerja siswa.

r) Guru menginformasikan kegiatan untuk pertemuan selanjutnya.

s) Guru mengakhiri kegiatan pembelajaran.

Informasi mengenai prosedur pelaksanaan circuit learning dan pembentukkan kelompok disampaikan guru pada saat memulai pelajaran, untuk pertemuan selanjutnya setiap anggota kelompok telah duduk di dalam kelompoknya masing-masing.

\section{METODE PENELITIAN}

Jenis penelitian ini adalah penelitian pra-eksperimen. Rancangan penelitian yang digunakan adalah randomized control group only design. Populasi dalam penelitian ini adalah semua siswa kelas Populasi dalam penelitian ini adalah semua kelas VIII SMPN 4 Lubuk Alung Tahun Pelajaran 2016/2017, yang terdiri dari 4 kelas. Teknik pengambilan sampel secara proposive sampling. Berdasarkan pertimbangan tersebut maka dipilih kelas $\mathrm{VIII}_{2}$ dan kelas $\mathrm{VIII}_{3}$ sebagai sampel, dari kedua kelas sampel dipilih secara acak sehingga terpilih $\mathrm{VIII}_{3}$ sebagai kelas eksprimen dan $\mathrm{VIII}_{2}$ sebagai kelas kontrol. Perlakuan yang diberikan kepada kelas eksperimen adalah menerapkan model pembelajaran kooperatif tipe circuit learning dan pada kelas kontrol adalah menerapkan pembelajaran konvensional. Setelah penelitian berakhir kelas eksperimen dan kelas kontrol diberikan tes untuk melihat hasil belajar matematika kedua kelas tersebut.

Pembelajaran pada kelas eksperimen dilakukan dengan tiga tahap yaitu persiapan, pelaksanaan dan penutup. Pada tahap persiapan kegiatan yang dilakukan adalah:

a) Guru mengucapkan salam dan mengarahkan siswa untuk memimpin doa. 
b) Guru mengecek kehadiran siswa.

c) Guru memberikan apersepsi tentang konsep materi yang akan dipelajari.

d) Guru memberikan motivasi tentang kegunaan materi pembelajaran dalam kehidupan sehari-hari.

e) Guru menempelkan gambar materi ajar didepan kelas dan memberikan pertanyaan kepada siswa.

f) Guru menempelkan peta konsep dan menjelaskan tentang peta konsep tersebut.

g) Guru membagi siswa dalam beberapa kelompok dan membagikan lembar kerja.

h) Guru menjelaskan bahwa setiap kelompok harus mengisi lembar kerja siswa dan mengisi bagian dari peta konsep sesuai dengan bahasa mereka sendiri.

i) Guru menjelaskan bahwa bagian dari peta konsep yang mereka kerjakan akan dipresentasikan.

Tahap pelaksanaan kegiatan yang dilakukan secara umum adalah:

a) Peserta didik bersama kelompoknya mendiskusikan lembar kerja yang diberikan guru.

b) Semua anggota kelompok kemudian saling bertukar pikiran dan mendiskusikan masalah yang telah diberikan oleh guru kemudian membuat laporan hasil diskusi.

c) Setelah selesai berdiskusi guru memberikan kesempatan kepada setiap kelompok untuk mempresentasikan peta konsep yang mereka buat dengan bahasa sendiri.

d) Setiap kelompok tampil ke depan kelas untuk mempresentasikan hasil diskusinya.

e) Guru memberikan penguatan berupa pujian atas hasil presentasi yang bagus serta memberikan semangat kepada mereka yang belum dapat pujian atau hadiah untuk berusaha lebih giat.

f) Guru menjelaskan kembali hasil diskusi siswa tersebut agar wawasan siswa menjadi lebih luas.

Tahap penutup, kegiatan yang dilaksanakan adalah:

a) Guru memancing siswa untuk membuat rangkuman.

b) Guru melakukan penilaian terhadap hasil kerja siswa.

c) Guru menginformasikan kegiatan untuk pertemuan selanjutnya.

d) Guru mengakhiri kegiatan pembelajaran.

Penilaian hasil belajar ranah kognitif dilakukan melalui tes pada akhir kegiatan penelitian, pada tes akhir digunakan 25 soal objektif dengan 5 option yang diperoleh dari 40 soal yang telah diuji cobakan dan memenuhi kriteria indek kesukaran, daya beda dan reabilitas tes. Analisis pengujian hipotesis menggunakan uji-t, untuk mengetahui apakah terdapat pengaruh model pembelajaran kooperatif tipe circuit learning terhadap hasil belajar matematika siswa. Sebelum dilakukan uji-t terlebih dahulu dilakukan uji normalitas dan uji homogenitas kedua kelas sampel.

\section{HASIL DAN PEMBAHASAN}

Penelitian ini dideskripsikan pada data hasil belajar siswa yang belajar dengan menggunakan model pembelajaran kooperatif tipe circuit learning pada kelas eksperimen dan data hasil belajar siswa yang belajar dengan menggunakan pembelajaran konvensional pada kelas kontrol. Penilaian hasil belajar ranah kognitif dilakukan melalui tes pada akhir kegiatan penelitian, pada tes akhir digunakan 25 soal objektif dengan 5 option yang diperoleh dari 40 soal yang telah diuji cobakan terlebih dahulu. Perhitungan data hasil belajar tes akhir ranah kognitif, didapatkan nilai rata-rata $(\underline{x})$, dan persentase ketuntasan belajar kelas eksperimen dan kelas kontrol seperti pada Tabel 1.

Tabel 1

Deskripsi Data Tes Akhir Pada Kedua Kelas Sampel Tabel 4.1 Deskripsi Data Tes Akhir Kedua Kelas Sampel

\begin{tabular}{cccccccc}
\hline Kelas & $\mathbf{N}$ & $\underline{X}$ & \multicolumn{1}{c}{$\mathbf{S}^{\mathbf{2}}$} & $\mathbf{S}$ & $\mathrm{Xmax}$ & $\mathrm{X}_{\min }$ \\
\hline Eksperimen & 24 & 79,3 & 64,93 & 8,06 & 92 & 64 \\
Kontrol & 24 & 70 & 80,69 & 8,98 & 88 & 56 \\
\hline
\end{tabular}

Tabel 1 terlihat bahwa rata-rata hasil belajar siswa pada kelas eksperimen yang belajar dengan strategi circuit learning memiliki nilai rata-rata lebih tinggi dibandingkan dengan pembelajaran pada kelas kontrol. Nilai tertinggi pada kelas eksperimen 92 dan nilai terendah 64 sedangkan nilai tertinggi pada kelas kontrol 
88 dan nilai terendah 56. Hal ini berarti nilai rata-rata kelas eksperimen dengan strategi circuit learning lebih baik dari pada pembelajaran pada kelas kontrol.

Berdasarkan penelitian yang telah dilakukan diperoleh data dari lembaran observasi yang diisi oleh obsever selama penelitian berlangsung pada kelas eksperimen dan kelas kontrol. Aktifitas belajar ranah afektif siswa diperoleh setelah dilakukan analisis data pada semua lembaran observasi. Pengolahan data aktifitas belajar pada ranah afektif didapat nilai rata-rata $(\underline{x})$ untuk kedua kelas sampel. Nilai rata-rata ranah afektif dapat dilihat pada Tabel 2.

Tabel 2

Aktifitas Belajar pada Ranah Afektif Kelas Sampel

\begin{tabular}{ccccc}
\hline Kelas & N & Skor Max & Skor Min & $\underline{x}$ \\
Ekperimen & 24 & 79 & 68 & $\mathbf{7 3 , 2 9}$ \\
Kontrol & 24 & $\mathbf{7 7}$ & $\mathbf{6 0}$ & $\mathbf{6 7 , 9 2}$ \\
\hline
\end{tabular}

Berdasarkan Tabel.2 memperlihatkan bahwa nilai rata-rata aktifitas siswa pada kelas ekperimen adalah 73,29 sedangkan kelas kontrol adalah 67,92.

\section{Analisis Data}

Analisis data bertujuan untuk mengetahui pengaruh strategi circuit learning terhadap hasil belajar matematika siswa dimana hasil belajar siswa kelas eksperimen lebih tinggi dari pada kelas kontrol maka diyakini bahwa hasil ini akan mengakibat pengaruh dari perlakuan yang diberikan. Untuk mengetahui perbedaan antara kedua perlakuan ini bermakna atau tidak, maka data hasil belajar siswa dianalisa secara statistik. Sebelum melakukan uji hipotesis terlebih dahulu dilakukan uji normalitas dan uji homogenitas variansi pada ranah kognitif sebagai syarat-syarat yang harus dipenuhi.

Uji normalitas merupakan salah satu persyaratan pokok yang harus terpenuhi dalam pengujian hipotesis untuk melihat apakah kedua kelas sampel berdistribusi normal. Uji normalitas data dilakukan dengan uji lilifors. Berdasarkan perhitungan uji normalitas diperoleh harga $\mathrm{L}_{0}$ dan $\mathrm{L}_{\text {tabel }}$ pada taraf nyata 0,05, seperti terlihat pada Tabel 3 .

Tabel 3

Hasil Uji Normalitas Data Hasil Belajar Siswa

\begin{tabular}{ccccc}
\hline Kelas & $\mathrm{N}$ & L0 & L $_{\text {tabel }}$ & Keterangan \\
\hline Eksperimen & 24 & 0,13 & 0,19 & Berdistribusi normal \\
Kontrol & 24 & 0,17 & 0,19 & Berdistribusi normal \\
\hline
\end{tabular}

Berdasarkan Tabel 3 diperoleh $\mathrm{L}_{0}<\mathrm{L}_{\text {tabel, }}$ hal ini dapat disimpulkan bahwa data hasil belajar matematika siswa pada kedua kelas sampel berdistribusi normal.

Uji homogenitas variansi bertujuan untuk melihat apakah kedua kelas sampel memiliki variansi homogen atau tidak. Uji homogenitas variansi ini dilakukan dengan uji $\mathrm{F}$ pada taraf nyata $\alpha=0,05$. Berdasarkan standar deviasi masing-masing kelompok sampel diperoleh harga $F_{\text {hitung }}$ dan $F_{\text {tabel }}$ seperti terlihat pada Tabel 4.

Tabel 4

Hasil Uji Homogenitas Data Hasil Belajar Siswa

\begin{tabular}{cccc}
\hline Kelas & Fh & F $_{t}$ & Keterangan \\
\hline Kelas eksperimen dan kelas control & 1,24 & 2,01 & Homogen \\
\hline
\end{tabular}

Berdasarkan Tabel 4 diperoleh $F_{\text {hitung }}<F_{\text {tabel }}$ dengan $F_{\text {hitung }}=1,24$ dan $\quad F_{\text {tabel }}=2,01$. Hal ini dapat disimpulkan bahwa kedua kelas memiliki variansi yang homogen.

Hasil uji normalitas dan homogenitas data tes akhir diperoleh kedua kelas sampel berasal dari populasi yang berdistribusi normal dan mempunyai variansi yang homogen, maka untuk penguji hipotesis digunakan uji-t. Berdasarkan data akhir hasil belajar siswa dan pengolahan uji-t yang dilakukan, maka diperoleh $t_{\text {hitung }}$ $=3,89$ dan $t_{\text {tabel }}=1,677$ pada taraf kepercayaan 95\% dengan $\mathrm{dk} 46$. Diperoleh $\mathrm{t}_{\text {hitung }}>\mathrm{t}_{\text {tabel }}$ maka keputusannya adalah $\mathrm{H}_{0}$ ditolak dan $\mathrm{H}_{\mathrm{i}}$ diterima. Dapat disimpulkan bahwa hasil belajar matematika siswa 
kelas VIII SMPN 4 Lubuk Alung dengan strstegi circuit learning lebih baik dari siswa yang menggunakan pembelajaran biasa.

Analisis data pada ranah afektif dilakukan perhitungan untuk mendapatkan nilai rata-rata proporsi kelas eksperimen dan kelas kontrol dapat dilihat pada Tabel 5.

Tabel 5

Deskripsi Data pada Ranah Afektif

\begin{tabular}{cccccc}
\hline Kelas & $\mathrm{N}$ & $\mathrm{X}$ & $\mathrm{P}$ & $\mathrm{Z}_{\mathrm{t}}$ & $\mathrm{Z}_{\mathrm{h}}$ \\
\hline Eksperimen & 24 & 24 & $100 \%$ & \multirow{2}{*}{1,64} & \multirow{2}{*}{3,83} \\
Kontrol & 24 & 13 & $67 \%$ & \\
\hline
\end{tabular}

Berdasarkan Tabel 5 memperlihatkan bahwa banyak siswa yang berkelakukan baik pada kelas eksperimen adalah 24 siswa dan pada kelas kontrol adalah 13 siswa. Hasil perhitungan proporsi didapat Zhitung $=3,83$ dan $\mathrm{Z}_{\text {tabel }}=1,64$ maka $Z_{\text {hitung }}>\mathrm{z}_{\text {tabel}}$, hal ini dapat disimpulkan bahwa hasil aktivitas belajar siswa pada kelas ekperimen lebih baik dari pada hasil aktivitas belajar siswa kelas kontrol.

Berdasarkan analisis data diperoleh rata-rata hasil belajar matematika siswa kelas eksperimen adalah 79,3 dan rata-rata hasil belajar matematika siswa kelas kontrol adalah 70, maka dapat disimpulkan bahwa hasil belajar matematika siswa kelas eksperimen lebih baik dari pada kelas kontrol. Berdasarkan hasil analisis dari lembaran observasi pada ranah afektif diperolehrata-rata aktifitas siswa kelas ekperimen adalah 72,9 dan rata-rata aktifitas siswa pada kelas kontrol adalah 66,9 maka terlihat bahwa nilai rata-rata kelas eksperimen lebih baik dari pada rata-rata kelas kontrol. Hasil analisis data dengan uji statistik menunjukkan bahwa penerapan strategi circuit learning dapat berpengaruh terhadap hasil belajar matematika siswa menjadi lebih baik.

Strategi circuit learning diterapkan pada kelas eksperimen, circuit learning bertujuan untuk memberikan kesempatan pada siswa untuk berlatih dan mempelajari keterampilan berfikir yang dibutuhkan dalam penyelesaian masalah yang efektif dan membantu siswa belajar membandingkan dan membedakan barbagai macam solusi. Pembelajaran di kelas eksperimen menunjukkan beberapa perkembangan dan keunggulan selama pelaksanaan, diantaranya siswa lebih aktif, kritis, analistis dan termotivasi serta siswa tertarik dalam pembelajaran. Siswa mulai terbiasa membangun konsep dan prinsip matematika dengan pengalaman siswa sebelumnya dan keterampilan dalam berdiskusi kelompok dapat membangkitkan rasa ingin tahu tentang hal-hal baru. Berikut ini adalah gambar siswa yang sedang diskusi yang terdapat pada Gambar 1.

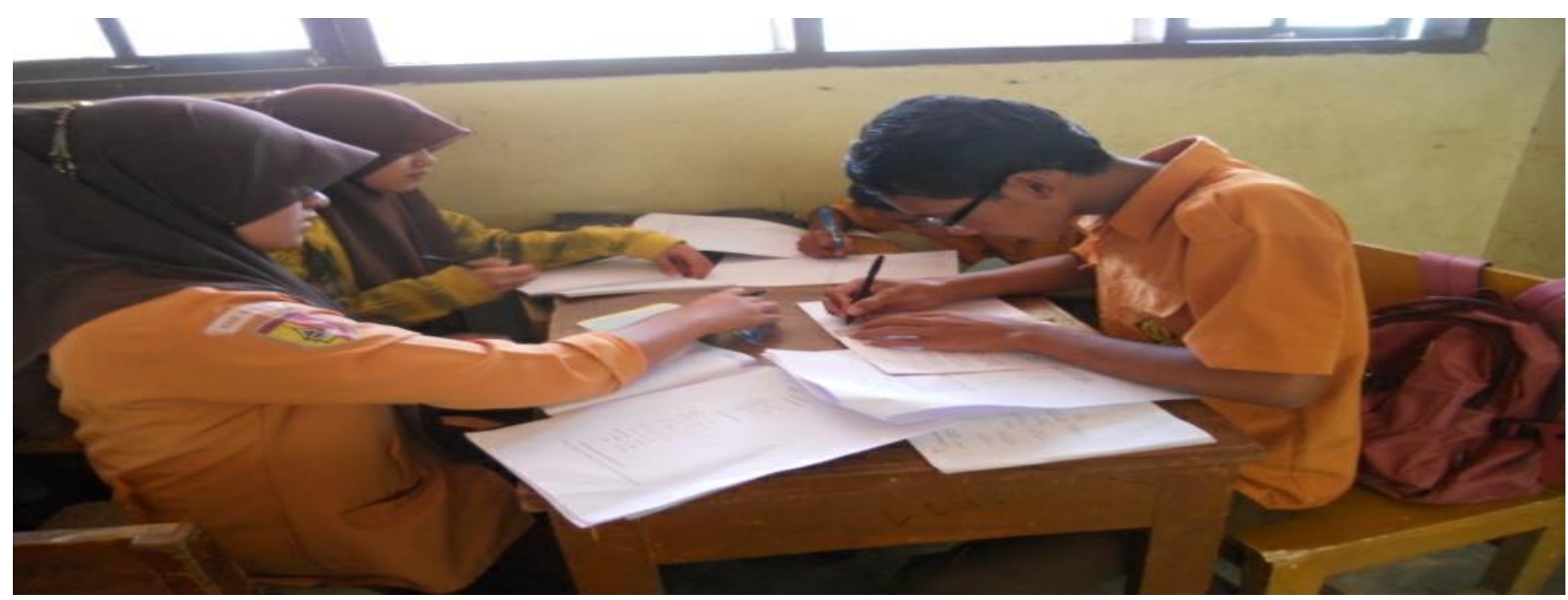

Gambar 1. Siswa sedang diskusi dan membuat jawaban pertanyaan pada lembar jawaban

Berdasarkan Gambar 1 siswa tertarik dan termotivasi dalam pembelajaran, hal tersebut terlihat dari antusias dan rasa ingin tahu siswa dalam belajar matematika semakin meningkat dari pertemuan pertama hingga pertemuan terakhir. Motivasi siswa sangat penting sekali karena dapat mendorong siswa untuk dapat melakukan aktifitas dalam pembelajaran agar memperoleh tujuan yang diharapkan yaitu penguasaan konsep 
yang baik agar bisa mempengaruhi hasil belajar matematika siswa. Hal tersebut sesuai dengan pendapat Erman (2003:19) "belajar ialah suatu proses usaha yang dilakukan seseorang untuk memperoleh suatu perubahan tingkah laku yang baru secara keseluruhan, sebagai hasil pengalamannya sendiri dalam interaksi dengan lingkungannya".

Siswa kelas eksperimen lebih memahami dan menguasai konsep dibandingkan siswa kelas kontrol. Hal tersebut terjadi karena pengaruh strategi circuit learning yang diterapkan pada pembelajaran kelas eksperimen. Guru membimbing dan memberikan kesempatan kepada siswa melakukan aktifitas menganalisis untuk menemukan konsep dalam kelompok sesuai dengan masalahnya. Siswa harus memanfaatkan waktu agar dapat menyelesaikan setiap masalah yang diberikan dalam kelompoknya. Selain itu, siswa diberikan kesempatan pendapat atau ide yang dikemukakan oleh siswa tidak semuanya benar, namun pada saat itu guru tidak menyalahkan konsep yang dikemukakan siswa tetapi guru mengarahkan siswa pada konsepsi yang benar.

Siswa mempresentasikan hasil diskusi didepan kelas sehingga terjadi komunikasi banyak arah karena ada proses pertukaran pendapat atas konsep yang disampaikan. Siswa memperoleh kesimpulan dan memantapkan konsep yang benar dengan arahan guru. Hal ini sejalan dengan pendapat Suyitno (2004:2) "pembelajaran matematika adalah kegiatan guru dalam mengajarkan matematika kepada siswa yang di dalamnya terkandung upaya guru untuk menciptakan pelayanan terhadap kemampuan, potensi, minat, bakat yang beragam agar terjadinya interaksi optimal antara guru dengan siswa serta antara siswa dengan siswa”.

Gambaran pada kelas kontrol yaitu siswa kurang aktif dan kurang termotivasi karena di kelas cenderung tidak terlihat peningkatan dibanding kelas eksperimen. Siswa kurang antusias untuk menggali informasi sebanyak-banyak dari guru, siswa kebanyakan memilih diam dari pada bertanya pada guru. Pada saat guru memberikan kesempatan untuk bertanya hanya beberapa siswa saja yang bertanya, siswa yang lain hanya diam. Siswa kesulitan mengerjakan soal yang bervariasi dan meninggalkan soal yang tingkat kesulitannya tinggi serta tidak mau berdiskusi untuk memecahkan soal yang diberikan.

Kendala yang dihadapi dalam penelitian ini adalah pada pertemuan awal penerapan metode ini siswa masih canggung dan tidak terbiasa dengan cara tersebut, sehingga masih banyak bimbingan dari guru. Pada saat berdiskusi masih ada siswa yang kurang aktif karena kurangnya pemerataan kemampuan dalam mengkontruksikan pemikirannya. Untuk mengatasi kendala tersebut, hal yang dilakukan peneliti diantaranya adalah guru mengawasi jalannya diskusi agar berjalan optimal dan guru berkeliling untuk memberikan bimbingan kepada siswa/kelompok yang mengalami kesulitan untuk menyelesaikan tugas kelompoknya dengan baik. Guru memotivasi siswa agar semua siswa ikut serta mengeluarkan pendapat atau ide-idenya ketika mencari jawaban dari rumusan masalah yang telah diberikan. Walaupun terdapat kendala selama penelitian, namun banyak peningkatan dari pertemuan pertama hingga pertemuan terakhir. Secara keseluruhan strategi circuit learning dapat meningkatkan keaktifan siswa dalam belajar sehingga meningkatkan hasil belajar matematika siswa.

\section{SIMPULAN}

Berdasarkan data hasil analisis dan pembahasan diperoleh nilai rata-rata hasil belajar matematika siswa pada ranah kognitif yang pembelajarannya dengan strategi circuit learning yaitu 79,3 dan kelas yang tidak menerapkan strategi circuit learning yaitu 70. Demikian juga nilai rata-rata aktivitas belajar matematika siswa pada ranah afektif yang pembelajarannya dengan strategi circuit learning yaitu 72,9 dan kelas yang tidak menerapkan pembelajaran strategi circuit learning yaitu 66,9.

Berdasarkan uji statistik pada ranah kognitif dilakukan dengan uji-t diperoleh $\left(\mathrm{t}_{\text {hitung }}=3,89\right)>\left(\mathrm{t}_{\text {tabel }}=\right.$ 1,677), maka strategi circuit learning lebih baik dari pembelajaran konvensional. Demikian juga analisis pada ranah afektif digunakan uji perbedaan rata-rata dua proporsi diperoleh $\left(\mathrm{Z}_{\text {hitung }}=3,83\right)>\left(\mathrm{Z}_{\text {tabel }}=1,64\right)$, maka aktivitas siswa pada strategi circuit learning lebih baik dari pembelajaran konvensional. Jadi, dapat disimpulkan bahwa terdapat pengaruh strategi circuit learning terhadap hasil belajar matematika siswa.

Berdasarkan kesimpulan yang diperoleh dalam penelitian ini, maka dapat dikemukakan saran-saran sebagai berikut:

1. Strategi circuit learning dapat digunakan sebagai salah satu alternatif bagi guru dalam usaha meningkatkan hasil belajar siswa.

2. Penelitian ini masih terbatas pada ranah kognitif dan ranah afektif saja. Diharapkan untuk penelitian lebih lanjut dilakukan pengamatan terhadap aspekpsikomotor. 


\section{DAFTAR PUSTAKA}

Arikunto, Suharsimi.2010. Prosedur Penelitian. Jakarta: Rineka Cipta 2012. Dasar - Dasar Evaluasi Pendidikan. Jakarta: Bumi Aksara.

Huda, miftahul. 2014. Model-Model Pengajaran Dan Pembelajaran. Malang: Pustaka Pelajar.

Sudjana. 2005. Metoda Statistika. Bandung: Tarsito.

Suyitno. 2004 Dasar-Dasar Dan Proses Pembelajaran Matematika 1. Semarang FMIPA UNNES.

Tim STKIP YDB Lubuk Alung. 2011.Buku Panduan Penulisan Skripsi Sekolah Tinggi Keguruan dan Ilmu Pendidikan. STKIP YDB Lubuk Alung.

Yohanes. 2012. Pendekatan Strategi Metode Teknik Dan Model Pembelajaran. Padang : Universitas Negeri Padang. 